\title{
Protein Induced by Vitamin K Absence-II Measurement
}

National Cancer Institute

\section{Source}

National Cancer Institute. Protein Induced by Vitamin K Absence-/l Measurement. NCI

Thesaurus. Code C150846.

The determination of the amount of protein induced by vitamin $\mathrm{K}$ absence-II present in a sample. 